\title{
Evaluation of Oat Extracts on the Efficiency of Lime in Soil
}

\author{
Marcelo E. Cassiolato ${ }^{1}$, Anderson R. Meda ${ }^{1}$, Marcos A. Pavan ${ }^{2}{ }^{\bullet}$, Mário Miyazawa ${ }^{2}$ and \\ José C. de Oliveira ${ }^{2}$ \\ ${ }^{1}$ Bolsista PIBIC/CNPq/Instituto Agronômico do Paraná; ${ }^{2}$ Instituto Agronômico do Paraná, C. Postal 48l, CEP \\ 86001-970, Londrina, PR, Brazil
}

\begin{abstract}
The low mobility of the soluble components of surface-applied lime, limits their ability to reduce subsoil acidity in variable charge soils. Laboratory experiments were conducted with brazilian Oxisol to evaluate the effect of oat extracts on the mobility of surface applied calcium in form of $\mathrm{CaCO}_{3}$. The following oat cultivars were evaluated: Argentina 5VL3, UPF 90H400-2, IAPAR 61, IA96101-b, SI 83400, EMBRAPA 29, LD 9102, FAPA 1, ER 93247, ER 90148, ER 89144, ER 93152, Alpha 94124, Alpha 94206 and Preta comum. Oat extracts and lime were applied at rates of 10 and $5 \mathrm{Mg} \mathrm{ha}^{-1}$, respectively. Effect of lime without plant extracts on soil acidity was limited in the upper $10 \mathrm{~cm}$ of the profile. Lime in the presence of oat extracts increased $\mathrm{pH}$ and $\mathrm{Ca}_{e x}$ and decreased $\mathrm{Al}_{\text {ex }}$ about $20 \mathrm{~cm}$ deep. The SI83400 and UPF90H400-2 were the best oat extracts as Ca-carrier into the acid soil profile. The results suggested that soluble organic compounds from oat extracts are mobile and capable of detoxifying acid subsoil, by increasing liming efficiency.
\end{abstract}

Key words: subsoil acidity, Ca-leaching, plant residue.

\section{INTRODUCTION}

Large areas in Brazil contain acid soils and some of which have subsoil acidity (Olmos \& Camargo, 1976). Acid subsoils contain toxic levels of Al or deficient amount of $\mathrm{Ca}$ which restrict root proliferation (Ritchey, 1981). The major consequence of subsoil acidity is drought stress. The efficacy of surface-applied lime in neutralizing subsoil acidity is uncertain. In some case no effect was observed (Pavan et al., 1984) in others lime effect is quite rapid (Oliveira \& Pavan, 1996).

Many examples have been presented in the literature to demonstrate that alkalinity can be leached to subsoil by the additions of organic compounds on the soil surface. Wright et al. (1985) showed that dolomitic lime in the presence of cow manure increased subsoil $\mathrm{pH}$ and decreased exchangeable $\mathrm{Al}$ whereas lime alone had no effect. Oliveira \& Pavan (1996) demonstrated that lime applied on soil surface under no tillage with high amount of plant residue serving as mulch, had its effects extended to a depth of $60 \mathrm{~cm}$, increasing $\mathrm{pH}$ and $\mathrm{Ca}$ and decreasing $\mathrm{Al}$ contents. Miyazawa et al. (1998), Pavan \& Miyazawa (1998) and Ziglio et al. (1999) showed that black oat residue improved the efficiency of liming, increasing $\mathrm{pH}$ and $\mathrm{Ca}$ and reducing $\mathrm{Al}$ in the subsoil profile. They also reported that wheat residue had no effect in lime efficiency. They concluded that a range of low molecular weight organic acids are produced in soil from the decomposition of organic matter. Although these organic acids are considered to be short-lived in soils, their continual production makes their anions important in acid soil chemistry.

The objective of this work was to evaluate the efficiency of oat extracts on the effect of soil surface-applied lime.

\section{MATERIAL AND METHODS}

\section{Plant sampling}

Fifteen black and white oat cultivars were planted in the Instituto Agronômico do Paraná (IAPAR) experimental station at Londrina, Brazil $\left(23^{\circ} 20^{\prime} \mathrm{S}\right.$ and $51^{\circ} 08^{\prime} \mathrm{W}$ ) during 1998 spring season. The cultivars were: Argentina 5VL3, UPF 90H400-2,

\footnotetext{
- Author for correspondence
} 
IAPAR 61, IA96101-b, SI 83400, EMBRAPA 29, LD 9102, FAPA 1, ER 93247, ER 90148, ER 89144, ER 93152, Alpha 94124, Alpha 94206 and Preta comum. At the maximum growing stage, shoot samples were collected from each cultivar, dried at $65^{\circ} \mathrm{C}$ during $72 \mathrm{~h}$ in a forced drath oven, finely ground to pass $1 \mathrm{~mm}$ sieve and stored in paper bags. Sub samples were then chemically analyzed by standard procedure used at IAPAR (Miyazawa et al., 1992). Plant extract solution was obtained by the following procedure: transfer $3.0 \mathrm{~g}$ (equivalent to $10 \mathrm{Mg} \mathrm{ha}^{-1}$ ) of dried plant material to centrifuge tube, add $150 \mathrm{ml}$ of water (corresponding to 1 soil porous volume-pv), shake for 8 hours and filter.

\section{Soil sampling}

A bulk of soil material was collected from the 0-20 $\mathrm{cm}$ horizon of an uncultivated red dark latosol (Oxisol). The soil material was air dried and ground to pass through a $2 \mathrm{~mm}$ screen before being treated. Sub sample was analyzed by the standard procedure used at IAPAR (Pavan et al., 1992). It had an original $\mathrm{pHCaCl}_{2}$ value of 4.10; exchangeable $\mathrm{Al}, \mathrm{Ca}, \mathrm{Mg}$, and $\mathrm{K}$ contents of 11.1, $3.70,1.70$ and $0.50 \mathrm{mmol} \mathrm{dm}^{-3}$, respectively; total acidity $(\mathrm{H}+\mathrm{Al})$ of $62.0 \mathrm{mmol} \mathrm{\textrm {dm } ^ { - 3 }}$; and total carbon content of $7.64 \mathrm{~g} \mathrm{~kg}^{-1}$. The clay content was $27 \%$, silt $2 \%$ and sand $71 \%$.

\section{Experimental treatments}

Soil sample was transferred to a PVC column (25 $\mathrm{cm}$ high and $4 \mathrm{~cm}$ of diameter) and compacted to a homogeneous bulk density (mean $1 \mathrm{~g} \mathrm{~cm}^{-3}$ ) corresponding to natural conditions. Calcium carbonate was added on the soil surface in an amount required to neutralize $200 \%$ of the total soil acidity $(\mathrm{H}+\mathrm{Al})$ at a depth of $5 \mathrm{~cm}$. Plant extract solutions were added at a rate of $1 \mathrm{ml} \mathrm{min}$ ${ }^{1}$. Then $150 \mathrm{ml}$ of deionized water was added (1pv). This was done three times, to a total of $3 \mathrm{pv}$. Each time, the leachate $(1 \mathrm{pv})$ was collected in plastic bottles attached at the bottom of the soil column. All treatments had three replicates in a completely randomized block design. The leachates were analyzed for $\mathrm{pH}, \mathrm{Al}$ and $\mathrm{Ca}$. Soil samples were taken from each replicate at the following depths: $0-5,5-10,10-15,15-20$, and $20-25 \mathrm{~cm}$. The soil samples were air dried, ground to pass $2 \mathrm{~mm}$ sieve, and analyzed for $\mathrm{pH}$ and exchangeable $\mathrm{Al}$ and $\mathrm{Ca}$. The soil $\mathrm{pH}$ was determined in $0.01 \mathrm{~mol} \mathrm{~L}^{-1} \mathrm{CaCl}_{2}$ suspension (1:2.5 soil:solution ratio) after shaking for $1 \mathrm{~h}$; exchangeable $\mathrm{Al}$ and $\mathrm{Ca}$ were extracted with $\mathrm{N} \mathrm{KCl}$ solution in a 1:10 soil:solution ratio and 10 minutes shaking time. $\mathrm{Al}$ was determined by titration with standardized $0.015 \mathrm{~N} \mathrm{NaOH}$ solution using bromotymol blue indicator and $\mathrm{Ca}$ by atomic absorption spectroscopy.

\section{RESULTS AND DISCUSSION}

The soil $\mathrm{pH}, \mathrm{Ca}$, and $\mathrm{Al}$ by depth for the control treatment are shown in figures 1,2 , and 3 , respectively. These figures show the effects of control and the most and the least efficient oat extracts. The other extracts presented intermediate effects. Unamended soil profile (no lime, no extract) had lower $\mathrm{pH}$ (average 4.1), lower $\mathrm{Ca}$ (average $3.5 \mathrm{mmol} \mathrm{dm}^{-3}$ ) and higher $\mathrm{Al}$ (average $6.7 \mathrm{mmol} \mathrm{dm}^{-3}$ ). These chemical characteristics are believed to restrict root proliferation and crops are likely to respond to lime.

Additions of lime alone increased $\mathrm{pH}$ and $\mathrm{Ca}$, and decreased $\mathrm{Al}$ in the up $10 \mathrm{~cm}$ surface of the profile only (data not presented). These results confirm the low efficacy of surface applied lime in reducing subsoil acidity in variable charge soil, corroborating data presented in previous study with brazilian soils (Pavan et al., 1984).

Application of lime in the presence of oat extracts markedly increased soil $\mathrm{pH}$ and $\mathrm{Ca}$ down to $20 \mathrm{~cm}$ depth and neutralized $\mathrm{Al}_{\text {ex }}$ down to $15 \mathrm{~cm}$ depth. These results indeed support the view that soluble organic compounds in soil are mobile and capable of detoxifying acid subsoils. Miyazawa et al. (1992) demonstrated that organic acids can detoxify $\mathrm{Al}^{3+}$ to an acid sensitive wheat cultivar. The SI83400 and UPF 90H400-2 were the best oat extracts as $\mathrm{Ca}$-carrier deeper in the soil profile, and ER 89144 was the least efficient. The UPF 90H400-2 was also the most efficient oat extract in reducing $\mathrm{Al}$ deeper in the soil profile (Figure 3).

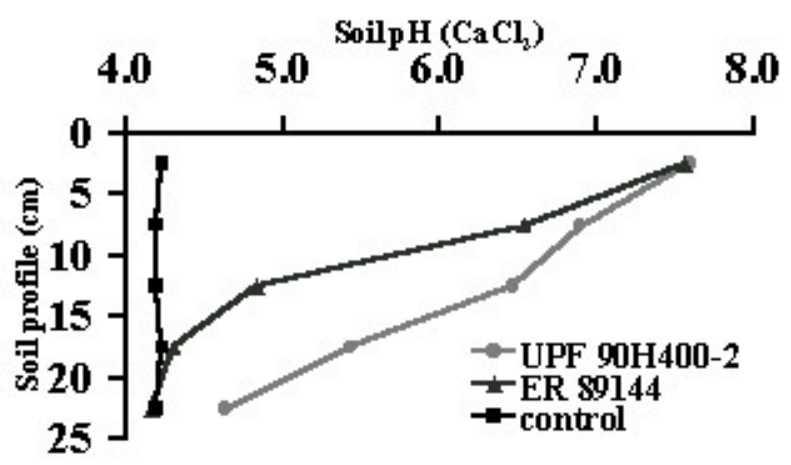

Figure 1 - The effects of oat extracts on soil $\mathrm{pH}$. 

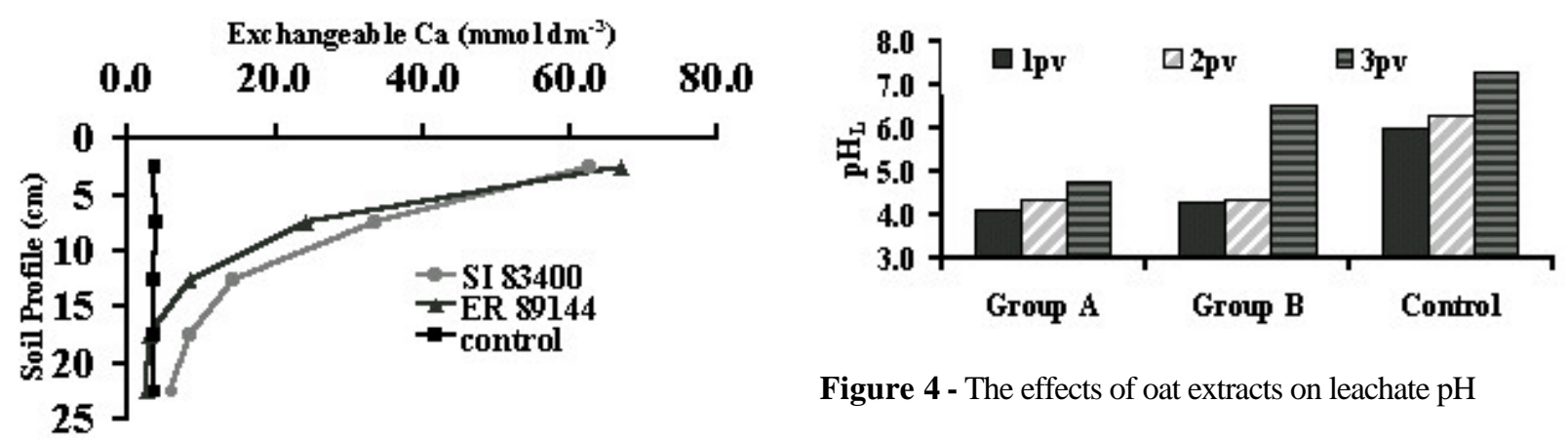

Figure 4 - The effects of oat extracts on leachate $\mathrm{pH}$

Figure 2 - The effects of oat extracts on soil $\mathrm{Ca}_{\mathrm{ex}}$.

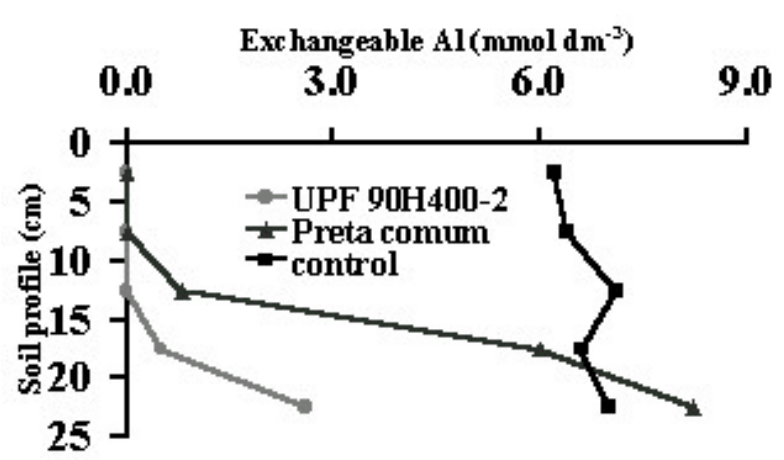

Figure 3 - The effects of oat extracts on soil $\mathrm{Al}_{\mathrm{ex}}$.

The results concerning the chemical analysis of the leachate $(\mathrm{pH}, \mathrm{Ca}$ and $\mathrm{Al})$ are presented in figures 4, 5, and 6. Unamended soil profile and limed soil surface without plant extracts showed low concentration of $\mathrm{Ca}$ in the leachate. Oat extratcs were separated in two groups: the least (A) and the most efficient (B) in increasing $\mathrm{pH}, \mathrm{Ca}$ and $\mathrm{Al}$, and they were compared with control. Increasing pv increased $\mathrm{pH}$ (dilution factor) and decreased leachate $\mathrm{Ca}$ and $\mathrm{Al}$. The group $\mathrm{A}$ for $\mathrm{pH}$ were: ALPHA 94206, ALPHA 94124, Preta comum, ER 93152, ER 89144, LD 9102, EMBRAPA 29, FAPA 1, ER 93247 and ER 90148. The group B for $\mathrm{pH}$ were: IAPAR 61, IA 96101-b, UPF 90H400-2, Argentina 5VL3 and SI 83400. The group A for Ca were: IA 96101-b, SI 83400, UPF 90H400-2, IAPAR 61 and Argentina 5 VL3. The group B for Ca were: FAPA 1, ER 90148, ER 93427, Preta comum, ALPHA 94214, LD 9102, ALPHA 94206, EMBRAPA 29, ER 93152 and ER 89144. The group A for Al were: IA 96101-b, IAPAR 61, UPF 90H400-2, SI 83400, Argentina 5VL3, ALPHA 94206, Preta comum, ALPHA 94124, ER 93152 and FAPA 1.

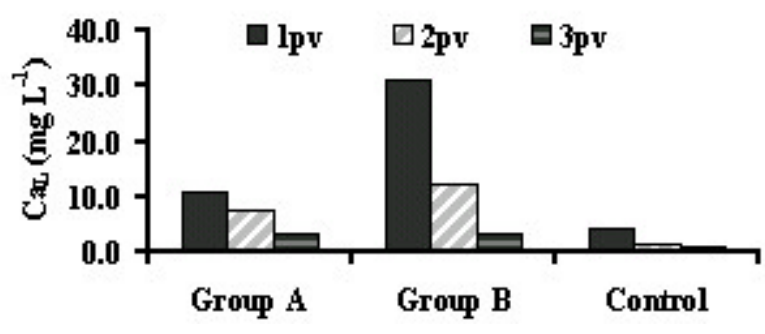

Figure 5 - The effects of oat extracts on leachate $\mathrm{Ca}$.

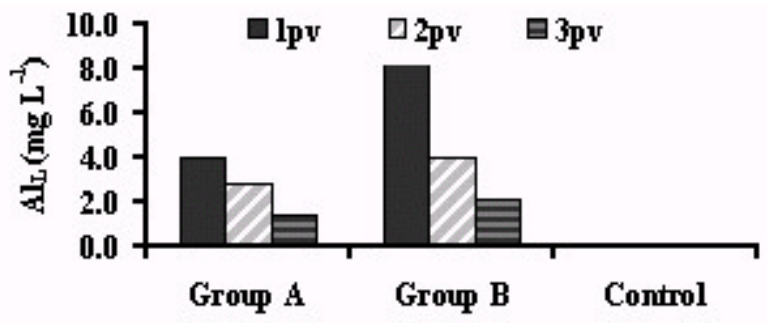

Figure 6 - The effects of oat extracts on leachate Al.

The group B for Al were: ER 90148, ER 89144, LD 9102, EMBRAPA 29 and ER 93247. Al was not detected in the leachate, for unamended soil profile. These results show again that surface lime application on variable charge soil presents minimal vertical movement. However liming soil surface with plant extracts enhanced leaching losses of $\mathrm{Ca}$ and $\mathrm{Al}$. The capacity of oat extract as Ca-carrier followed the order: SI $83400=$ UPF 90H400-2 > all the others. The capacity of oat extracts to detoxify $\mathrm{Al}$ followed the order: UPF 90H400-2 > SI83400 > IA 96101-b > IAPAR 61> Argentina 5VL3 $>$ LD $9102=$ ER $93247=$ FAPA $1>$ EMBRAPA $29=$ ALPHA $94124=$ ER 93125 $=$ ER $90148>$ ALPHA $94206>$ ER $89144>$ Preta comum. 


\section{CONCLUSIONS}

Soluble organic plant compounds from oat extracts improve the efficiency of surface-applied lime. The SI83400 and UPF 90H400-2 oat extracts were the most efficient as Ca-carrier in soil.

\section{RESUMO}

A baixa mobilidade dos componentes solúveis do calcário aplicado na superfície do solo limita a sua eficiência na redução da acidez das camadas subsuperficiais de solos com cargas variáveis. Foram conduzidos experimentos de laboratório com latossolo ácido para avaliar a eficiência de extratos de aveia na mobilidade do calcário aplicado na superfície do solo. Foram avaliadas as seguintes cultivares de aveia: Argentina 5VL3, UPF 90H400-2, IAPAR 61, IA96101-b, SI 83400, EMBRAPA 29, LD 9102, FAPA 1, ER 93247, ER 90148, ER 89144, ER 93152, Alpha 94124, Alpha 94206 and Preta comum. O calcário e a aveia foram aplicados em doses equivalentes a 5 e 10 $\mathrm{Mg} \mathrm{ha}{ }^{-1}$, respectivamente. O efeito da calagem sem resíduos vegetais limitou-se nos $10 \mathrm{~cm}$ superficiais do solo. A calagem na presença de extratos de aveia aumentou o $\mathrm{pH}$ e Ca-trocável e diminuiu Al-trocável até $25 \mathrm{~cm}$ de profundidade. As cultivares SI 83400 e UPF 90H400-2 foram as melhores transportadoras de Ca no perfil do solo. Os resultados sugerem que compostos solúveis contidos nos extratos de aveia, melhoram a eficiência do calcário aplicado na superfície dos solos.

\section{REFERENCES}

Miyazawa, M.; Chierice, G.O. \& Pavan, M.A. (1992). Amenização da toxidez de alumínio às raízes de trigo pela complexação com ácidos orgânicos. Rev. bras. Ci. Solo, 16:209-215.
Miyazawa, M.; Pavan, M.A. \& Franchini, J.C. (1998). Organic mobility of surface applied lime under notillage. In: International Meeting of the International Humic Substance Society, $9^{\text {th }}$. Adelaide 1998. Anais. Adelaide, International Humic Substances Society. p. 166.

Miyazawa, M; Pavan, M.A. \& Bloch, M.F.M. Análise química de tecido vegetal. IAPAR, 1992. (IAPAR, Circular, 74). $17 \mathrm{p}$.

Oliveira, E.L. de \& Pavan, M.A. (1996). The control of soil acidity in no-till system for soybean production. Soil Till. Res., 38:47-57.

Olmos, J.I.L. \& Camargo, M.N. (1976). Ocorrência de alumínio tóxico nos solos do Brasil, sua caracterização e distribuição. Ci. Cult., 28:171-180.

Pavan, M.A. \& Miyazawa, M. (1998). Mobilização do calcário no solo através de resíduos da aveia. In: Reunião da Comissão Brasileira de Pesquisa da Aveia, XVIII. Londrina 1998. Anais. Londrina, Instituto Agronômico do Paraná, p.72-79.

Pavan, M.A.; Bingham, F.T. \& Pratt, P.F. (1984). Redistribution of exchangeable calcium, magnesium, and aluminum following lime or gypsum applications to a brazilian oxisol. J. Soil Sci. Soc. Am., 48:33-38.

Pavan, M.A.; Bloch, M.F.M.; Zempulski, H. da C.; Miyazawa, M.; Zocoler, D.C. Manual de análise química do solo e controle de qualidade. IAPAR, 1992. (IAPAR, Circular, 76). 40 p.

Ritchey, K.D. (1981). Calcium leaching to increase rooting depth in a brazilian sawannah Oxisol. Agron. J., 72:40-44.

Wright, R.J.; Hern, J.L.; Baligar, V.C. \& Bennett, O.L. (1985). The effect of surface applied soil amendments on barley root growth in an acid subsoil. Comm. Soil Sci. Plant Anal., 16:179-192.

Ziglio, C.M.; Miyazawa, M. \& Pavan, M.A. (1999) Organic and inorganic forms of calcium mobilization in soil. Arq. Biol. Tecnol., 42(2):257-262.
Received: August 30, 1999; Revised: March 17, 2000; Accepted: May 16, 2000. 